\title{
PRESENTACIÓN
}

\section{Sobre la definición imposible del humor o la fluidez de la palabra}

\section{Laura Vazquez ${ }^{1}$}

Este volumen lleva por título "Humor gráfico: representaciones y usos" y propone un conjunto de artículos con el objetivo de consolidar un área de trabajo. Desde esta perspectiva, el volumen busca abordar el lenguaje en narrativa gráfica para debatir sobre el argumento hegemónico del arte, repensar la dimensión política de las representaciones visuales y problematizar los usos sociales de las mismas.

Me complace enormemente presentar esta edición porque pretende, también, funcionar como una intervención en "los márgenes del concepto" y problematizar esos bordes en los cuales el lenguaje se confunde con otra cosa, o sencillamente, desaparece. Quizá como nunca antes el humor gráfico se ha visto atravesado por la reflexión acerca de su propia consistencia. Sus contornos precisos se tornan borrosos y sus bordes inestables. Ya no estamos tan seguros de que sea posible asignarle al humor procedimientos retóricos precisos o circunscribir sus efectos. Por otra parte, gran parte de los problemas que suscita tienen que ver con la porosidad de fronteras entre el arte y el mercado. De ello, también trata este volumen.

Abordar los objetos, prácticas y contextos de las llamadas "narrativas gráficas" no puede ser otra cosa que una agenda en construcción. Durante buena parte del siglo veinte, sociólogos, comunicológicos pero también críticos y artistas, miraron "hacia otro lado" desentendiéndose de las historietas como materia de análisis e intervención crítica. Recién en los últimos años, asistimos a una transformación en este sentido lo que permite avizorar la concreción de un campo de estudios y un área especialización programática.

\footnotetext{
${ }^{1}$ Editora: Dra. Universidad de Buenos Aires - CONICET.
} 
Este volumen pretende formar parte de ese movimiento más amplio ya que gira en torno a la historia y el presente de la producción académica sobre historieta y humor gráfico. $\mathrm{Al} \mathrm{mismo}$ tiempo, se establece un contrapunto entre bibliografías globales y locales y ello es posible de ser rastreado en las citas bibliográficas de los autores. En los sistemas de referencias aquí utilizados y en los marcos teóricos que los sustentan, pueden advertirse las redefiniciones de los "estudios centrales", el debilitamiento de las disciplinas dominantes del campo y más específicamente, los nuevos problemas y preguntas que se formulan los investigadores. Es en este sentido que frente a una diversidad aparentemente irreducible, se torna necesario construir un proyecto de estudios compartido, de integración regional y avanzar en las perspectivas comparadas.

Durante años, los especialistas del campo, han estudiado la historia del cómic de los países centrales sin prestar atención a lo que ocurría en las historias nacionales o bien han puesto el acento en el desarrollo local dejando de lado el contexto en el que se insertaban esas prácticas, imaginarios y significados. Al mismo tiempo, decir "narrativas dibujadas" o "artes secuenciales" designa un coto de investigación de características difusas que si bien ha experimentado un desarrollo alentador, aún no se encuentra plenamente consolidado ya que presenta un conjunto de problemas metodológicos y teóricos que reclaman su atención por parte de los especialistas.

En tanto producto de la industria cultural, las narrativas de la imagen participan activamente en la conformación de subjetividades y en la construcción de identidades. Ya se sabe que el campo de los estudios de las culturas visuales comprende desde preguntas filosóficas del tipo “¿qué es una imagen?” hasta análisis más específicos situados en enclaves históricos determinados y ligados a las inflexiones culturales, políticas y sociales en las que se insertan esas producciones. En este sentido, si el lugar que ocupa la experiencia visual en la cultura moderna es una realidad ineludible, el humor gráfico como artefacto o como objeto no ha sido trabajado de igual modo que otros medios o dispositivos vinculados a la representación.

Las literaturas gráficas constituyen un tema relevante para distintas disciplinas en tanto lenguajes privilegiados para indagar la cultura, la sociedad y la política. De allí que el propósito es reparar en ciertos rasgos de un objeto vacante cuya presencia insoslayable promueve la constitución de un área de estudios programática y anclada en contextos históricos precisos.

Se entiende la imagen dibujada como un lugar de síntesis epistemológica de nuestras representaciones de lo real y como una sofisticada técnica de persuasión. Los distintos ensayos aquí reunidos proponen indagar en su materialidad para poner en escena sentidos, representaciones del poder, prácticas de resistencia y posibilidades de producción visual. Dar cuenta de las interrelaciones entre lenguaje y experiencia, entre imagen y representación, cultura de masas y mercado fueron ejes centrales en la elaboración del volumen que aquí presentamos. Desde este enfoque, los debates sobre las literaturas dibujadas y las artes secuenciales ameritan el desarrollo de una atención específica $y$, al mismo tiempo, interdisciplinaria. De allí que antes que postulados concluyentes, las intervenciones de este 
volumen encuentran su mejor forma en la superposición, combinación y amalgama de ideas y escenarios.

Ahora bien, el cambio de siglo, podría decirse, enfrentó al "humor gráfico" al límite de su propio nombre y con ello a una apertura insospechada de sus alcances y potencias. Esta edición de Antíteses da cuenta de la extenuación o fatiga de lo que alguna vez se definió categóricamente como "humor". La etiqueta es centrífuga y liminar y es así como el "humor gráfico" ya no es tanto una formar de nombrar como una gavilla de sentidos convergentes y divergentes. Sus límites y alcances nos muestran que las formas de hacer reír ya no son tal y como supimos, alguna vez, imaginarnos.

En las Artes Secuenciales hay plásticas narrativas y narrativas que son plásticas. Se trata de lectores de literatura y escritores de narrativa dibujada. Pero también de dibujantes que escriben y escritores que dibujan. Ello supone un tratamiento del relato que dificulta su encorsetamiento semántico. En este número, la meta final ha sido analizar las imágenes humorísticas como uno de los medios expresivos más singulares de la cultura contemporánea.

Finalmente, deseo expresar un especial agradecimiento a todos los especialistas e investigadores que colaboraron en esta edición y contribuyeron a pensar el campo del humor gráfico nacional e internacional. A los lectores, disfruten de la empresa. 